\title{
UWAGI NA TEMAT SPRAWIEDLIWOŚCI PROCEDURALNEJ MODELU SKARGI NA PRZEWLEKŁOŚĆ POSTEPOWANIA KARNEGO
}

\section{WĄTPLIWOŚCI NATURY KONSTYTUCYJNEJ}

Model postępowania zainicjowanego skargą na przewlekłość postępowania ukształtowany ustawa z 17 czerwca $2004 \mathrm{r}^{1}{ }^{1}$ nie przewiduje jakiejkolwiek formy weryfikacji orzeczeń sądowych zapadłych w wyniku skargi na przewlekłość postępowania. Przy takim rozwiązaniu legislacyjnym zawsze nasuwa się pytanie o konstytucyjność uregulowań nieprzewidujących możliwości zaskarżenia orzeczeń sądowych, o właściwy wzorzec kontroli przepisów lub wreszcie pytanie zasadnicze, czy ukształtowana w taki sposób procedura jest sprawiedliwa. Mimo że problem ten był już rozważany przez Trybunał Konstytucyjny oraz Sąd Najwyższy, dyskusja w tym przedmiocie trwa nadal.

Rozważania o sprawiedliwości proceduralnej z perspektywy konstytucyjnej rozpoczynają się od zasady demokratycznego państwa prawnego wyrażonej $\mathrm{w}$ art. 2 Konstytucji RP. O ile przepisy naruszające prawo strony do rozpoznania sprawy bez zbędnej zwłoki mogą być analizowane przez pryzmat wolności i praw człowieka, w szczególności art. 45 ust. 1 (prawo do sądu) $\mathrm{w}$ powiązaniu $\mathrm{z}$ art. 176 ust. 1 (dwuinstancyjność postępowania sądowego), art. 78 (prawo do zaskarżania orzeczeń i decyzji wydanych $\mathrm{w}$ pierwszej instancji), art. 77 (prawo do odszkodowania za niezgodne z prawem działanie organu władzy publicznej), czyli zasad pochodnych, o tyle wzorcem kontroli konstytucyjności przepisów naruszających prawa innego uczestnika postępowania - Skarbu Państwa -jest art. 2 Konstytucji RP, wyrażający zasadę demokratycznego państwa prawnego.

Przyczynek do dyskusji, w toku której akcentowano do tej pory głównie problemy ochrony praw strony, stanowi teza, że przepisy procedury rozpatrywania przewlekłości postępowania karnego naruszające prawa organu prowadzącego postępowanie i Skarbu Państwa, któremu w razie zgłoszenia udziału $\mathrm{w}$ postępowaniu przysługuja prawa strony, powinny być poddane kontroli konstytucyjnej z wzorcem wyrażonym w art. 2 Konstytucji RP.

\footnotetext{
${ }^{1}$ Ustawa z 17 czerwca 2004 r. o skardze na naruszenie prawa strony do rozpoznania sprawy w postępowaniu prowadzonym lub nadzorowanym przez prokuratora i postępowaniu sądowym bez nieuzasadnionej zwłoki, Dz. U. 2004, Nr 179, poz. 1843 ze zm. (dalej jako: ustawa o skardze na przewlekłość postępowania).
} 
Powszechnie uznaje się dynamiczny charakter formuły demokratycznego państwa prawnego. Trybunał Konstytucyjny w orzeczeniach stale wydobywa z konstytucyjnie wyrażonej zasady nowe zasady pochodne ${ }^{2}$. W zakresie procedury karnej w literaturze wyrażono stanowisko, że Trybunał Konstytucyjny do tej pory koncentrował się na rozbudowie, rekonstrukcji i interpretacji poszczególnych instytucji procesowych o charakterze gwarancyjnym, dopiero kolejnym krokiem będzie zbudowanie spójnego systemu gwarancji procesowych. Podnosi się, że rekonstrukcja ta powinna być oparta na szerokiej koncepcji rzetelności postępowania w ujęciu podmiotowym i przedmiotowym z uwzględnieniem praw nie tylko stron, lecz także wszystkich uczestników postępowania ${ }^{3}$.

Należy pamiętać, że ustawa o skardze na przewlekłość postępowania została wprowadzona do polskiego porządku prawnego pod wpływem orzecznictwa Europejskiego Trybunału Praw Człowieka w Strasburgu. Rozszerzając pole dyskusji na gwarantowanie praw wszystkich uczestników postępowania, w tym Skarbu Państwa, przydatne jest rozróżnienie poczynione przez Pawła Wilińskiego na dwa modele określenia podmiotowego zakresu zastosowania standardu rzetelnego procesu karnego: na model strasburski i haski. Pierwszy model właściwy jest dla krajów common law i Europejskiego Trybunału Praw Człowieka w Strasburgu, nacisk tu kładzie się na prawa oskarżonego. Model haski, którego nazwa pochodzi od siedziby Międzynarodowego Trybunału Karnego i Międzynarodowego Trybunału Karnego do Ścigania Osób Odpowiedzialnych za Poważne Naruszenia Międzynarodowego Prawa Humanitarnego Popełnione na Terytorium Byłej Jugosławii, charakteryzuje się szerszym zakresem podmiotowym, uwzględniającym nie tylko ochronę praw oskarżonego, lecz także innych uczestników postępowania, w tym pokrzywdzonego i świadków. Według P. Wilińskiego orzecznictwo Trybunału Konstytucyjnego zwraca się najbardziej ku orzecznictwu Europejskiego Trybunału Praw Człowieka, przez co nawiązuje do modelu strasburskiego ${ }^{4}$.

W postanowieniu z 21 września 2006 r. Trybunał Konstytucyjny rozważył charakter zakwestionowanego $\mathrm{w}$ skardze art. 8 ust. 2 ustawy o skardze na przewlekłość i wskazał, że przepis ten nie jest przepisem decydującym o konstytucyjnych prawach i wolnościach, a ma tylko charakter odsyłajacy. W ocenie Trybunału sam przepis nie daje żadnych praw, a jedynie tylko w powiązaniu z procedurą, do której odsyła, karna, cywilna, administracyjna. Sam art. 8 ust. 2 nie może zatem podlegać ocenie konstytucyjnej w oderwaniu od innych przepisów o charakterze merytorycznym, gdyż nie wynikają z niego żadne prawa podmiotowe ${ }^{5}$.

${ }^{2}$ W. Sokolewicz, Uwaga 6 do art. 2 Konstytucji, w: L. Garlicki (red.), Konstytucja Rzeczypospolitej Polskiej. Komentarz, t. 5, Warszawa 2007, s. 9.

${ }^{3}$ P. Wiliński, Rzetelny proces karny w świetle Konstytucji i orzecznictwa Trybunatu Konstytucyjnego, w: idem (red.), Rzetelny proces karny, Warszawa 2009, s. 349.

${ }^{4}$ P. Wiliński, op. cit., s. 360-361; idem, Dwa modele rzetelnego procesu karnego, „Państwo i Prawo” 2006, z. 7, s. 40-51. Autor zwraca uwagę, że rzetelność postępowania oddziałuje również na organy procesowe, które zobowiązane są do zapewnienia uczestnikom postępowania realnej możliwości realizacji swoich uprawnień.

${ }^{5}$ SK 10/06, OTK-A 2006, nr 8, poz. 117. Przepisem merytorycznym stanowiącym podstawę odrzucenia zażalenia był przepis art. $394^{1} \S 1$ i 2 k.p.c., do którego odwoływał się zaskarżony art. 8 ust. 2 , jednakże przepis ten nie został objęty skargą konstytucyjną przez skarżącego. 
Na tym tle rysuje się pytanie, czy to, że ustawa o skardze na przewlekłość postępowania nie przewiduje zaskarżalności orzeczeń w przedmiocie przewlekłości, jest zabiegiem celowym, czy też tak zwanym „,pominięciem” legislacyjnym. Jeżeli mamy do czynienia z tym ostatnim, to kwestia ta może być poddana pod osąd Trybunału Konstytucyjnego.

Kognicji Trybunału Konstytucyjnego nie podlegają zaniechania legislacyjne, to jest brak uchwalenia określonego aktu normatywnego, jednakże można poddać kontroli tak zwane pominięcie określonej regulacji w obowiązującym akcie normatywnym. Trybunał w wyroku z 1 kwietnia 2008 r. wskazał, że w kompetencjach Trybunału mieści się ocena konstytucyjności obowiązującego aktu prawnego $\mathrm{z}$ tego punktu widzenia, czy $\mathrm{w}$ jego przepisach nie brakuje unormowań, bez których może budzić wątpliwości natury konstytucyjnej. Jak wskazał Trybunał, ocenie podlega zawsze treść normatywna zaskarżonego przepisu, a więc także brak pewnych elementów normatywnych, których istnienie warunkowałoby konstytucyjność danej regulacji ${ }^{6}$. Przenosząc powyższe na grunt postępowania karnego, uregulowanie praw Skarbu Państwa w ustawie budzi wiele wątpliwości natury konstytucyjnej, gdyż zastosowanie przepisu odsyłającego do procedury karnej nie przydaje Skarbowi Państwa praw, za pomoca których mógłby wzruszyć zapadłe orzeczenie. Skarbowi Państwa nie przysługuje bowiem wachlarz innych środków prawnych dochodzenia swoich praw, które zostały zagwarantowane stronie.

Przepisy ustawy o skardze na przewlekłość odnoszące się do odpowiedzialności organów, których sposób procedowania zostaje zakwestionowany w skardze, można badać również w kontekście art. 1 Konstytucji RP, który mówi o zasadzie dobra wspólnego ${ }^{7}$. W doktrynie wyrażono pogląd, że państwo jako dobro wspólne funkcjonuje według zasad państwa demokratycznego, prawnego i sprawiedliwego, składaja się na to między innymi rzetelność działania władz publicznych, współpraca pomiędzy władzami i zasada pomocniczości. Przed dowolnością rozstrzygnięć organów państwowych zabezpieczać ma zasada poprawnej legislacji ${ }^{8}$.

Przy rozważaniu koncepcji „dobra wspólnego” w kontekście sprawiedliwości proceduralnej pomocny jest przykład dzielenia wspólnego tortu zaprezentowany przez Johna Rawlsa w Teorii sprawiedliwości. Analizując doskonała i niedoskonała sprawiedliwość proceduralną, dla zobrazowania tej pierwszej John Rawls podał przykład uczciwego (fair) podziału: „Pewna liczba osób ma podzielić ciasto: przy założeniu, że uczciwy podział to podział równy, jaka procedura (jeżeli w ogóle taka istnieje) da taki wynik? Nie wdając się w kwestie techniczne, narzuca się takie oto rozwiązanie, by ktoś podzielił ciasto i wziął

${ }^{6}$ SK 77/06, OTK-A ZU 2008, nr 3, poz. 39. Por. orzeczenie z 11 maja 1992 r., K 9/91, OTK 1992, poz. 6; uchwała z 1 czerwca 1994 r., W 4/94, OTK ZU 1995, nr 2, poz. 13; wyrok z 3 kwietnia 2001 r., K 32/99, Dz. U. Nr 32, poz. 385; wyrok z 3 grudnia 2002 r., P 13/02, OTK-A ZU 2002, nr 7, poz. 90; wyrok z 8 listopada 2004 r., K 38/03, OTK-A ZU 2004, nr 10, poz. 104; wyrok z 29 czerwca 2006 r., P 30/05, OTK-A ZU 2006, nr 6, poz. 70; postanowienie z 21 września 2006 r., SK 10/06, OTK-A ZU 2006, nr 8, poz. 117; wyrok z 23 czerwca 2008 r., P 18/06, OTK-A ZU 2008, nr 5, poz. 85.

${ }^{7}$ Por. M. Piechowiak, Prawnonaturalny charakter klauzuli dobra wspólnego, w: A. Choduń, S. Czepita (red.), W poszukiwaniu dobra wspólnego. Księga jubileuszowa Profesora Macieja Zielińskiego, Szczecin 2010, s. 597-611.

${ }^{8}$ W. Sokolewicz, Uwagi 10 i 36 do art. 2 Konstytucji, w: L. Garlicki (red.), op. cit., s. 14 i 47. 
ostatni kawałek, inni zaś mogli wybrać przed nim swoje. Podzieli on ciasto równo, ponieważ w ten sposób zapewni sobie największy możliwy udział. Przykład ten ukazuje dwie charakterystyczne cechy doskonałej sprawiedliwości proceduralnej: po pierwsze, istnieje niezależne kryterium uczciwego podziału, kryterium zdefiniowane odrębnie i uprzednio wobec przyjętej procedury postępowania; po drugie, możliwe jest zaprojektowanie procedury niezawodnie prowadzącej do pożądanego rezultatu" ${ }^{9}$. Według J. Rawlsa zasadnicza rzecz to istnienie niezależnego standardu pozwalającego rozstrzygnąć, jaki rezultat jest sprawiedliwy, oraz gwarantująca jego osiągnięcie procedura. Jako przykład niedoskonałej sprawiedliwości proceduralnej autor ten podał proces karny, gdyż nie da się stworzyć takich reguł prawnych, aby w każdej sytuacji osiagnięty został rezultat, upraszczając, w procesie karnym będą się zdarzać pomyłki: skazanie osoby niewinnej lub uniknięcie odpowiedzialności przez osobę winną. Odnosząc te rozważania na pożądany rezultat skargi na przewlekłość postępowania, nie sposób uznać, że jest to tylko zaspokojenie materialne strony i dyscyplinowanie organu, choćby w drodze niewłaściwie ukształtowanej procedury. Na przykład zasądzenie sumy pieniężnej w sytuacji, gdy do przewlekłości postępowania wcale nie doszło lub gdy w toku postępowania zainicjowanego skargą doszło do niepoddającej się konwalidacji pomyłki sądu. Niesłuszne zasądzenie od Skarbu Państwa sumy pieniężnej za przewlekłość, która w rzeczywistości nie wystąpiła, narusza dobro wspólne. Co więcej, nawet słuszne orzeczenie zapadłe w nieprawidłowo ukształtowanej procedurze nie będzie budzić zaufania, zarówno organów procesowych, jak i przeciwnej strony postępowania $^{10}$.

\section{WYBÓR MIĘDZY POSTĘPOWANIEM WPADKOWYM A PIERWOTNYM}

Konsekwencje przyjęcia modelu postępowania w przedmiocie skargi na przewlekłość jako postępowania wpadkowego (rozstrzygającego sprawę pochodną) albo pierwotnego (co do istoty sprawy) obrazuja dwie leżące na przeciwległych biegunach uchwały Sądu Najwyższego: uchwała z 28 czerwca 2005 r. (III SPZP 1/05) oraz uchwała z 23 marca 2006 r. (III SPZP 3/05). W pierwszej uchwale Sąd opowiedział się za pierwotnym charakterem postępowania $\mathrm{w}$ przedmiocie skargi na przewlekłość, natomiast w drugiej - za incydentalnym charakterem tego postępowania, przy czym stanowisko prezentowane $\mathrm{w}$ drugiej uchwale poparł $\mathrm{w}$ swym orzecznictwie Trybunał Konstytucyjny. Wybór między postępowaniem incydentalnym a pierwotnym rodzi konsekwencje w zakresie prawa do zaskarżenia.

9 J. Rawls, Teoria sprawiedliwości, tłum. M. Panufnik, J. Pasek, A. Romaniuk, S. Szymański, Warszawa 2009, s. 142.

${ }^{10}$ Por. M. Borucka-Arctowa, Zaufanie do prawa jako wartość spoteczna $i$ rola sprawiedliwości proceduralnej, w: Teoria prawa. Filozofia prawa. Wspótczesne prawo i prawoznawstwo, Toruń 1998, s. $15-28$. 
Sąd Najwyższy w uchwale z 23 marca 2006 r. (III SPZP 3/05) ${ }^{11}$ stwierdził, że na postanowienie $\mathrm{w}$ przedmiocie przewlekłości postępowania cywilnego zażalenie nie przysługuje, i postanowił o nadaniu uchwale mocy zasady prawnej ${ }^{12}$. Sąd tym samym odszedł od swojego stanowiska wyrażonego $\mathrm{w}$ uchwale z 28 czerwca 2005 r. (III SPZP 1/05) ${ }^{13}$, w której stwierdził, że przedmiotem postępowania w przedmiocie przewlekłości jest odrębna nowa sprawa, która dotyczy innych stron, stąd z dyspozycji art. 8 ust. 2 ustawy o skardze wynika, iż od postanowienia kończącego sprawę w postępowaniu wszczętym w wyniku skargi przed sądem pierwszej instancji przysługuje stronom zażalenie do sądu drugiej instancji, z wyjątkiem postanowienia kończącego sprawę $\mathrm{w}$ postępowaniu wszczętym w wyniku wniesienia skargi przed Sądem Najwyższym jako sądem pierwszej instancji. Odmienna wykładnia, według Sądu Najwyższego, byłaby niezgodna z Konstytucją. Sąd Najwyższy przypomniał, w kontekście szybkości postępowania i art. $6 \mathrm{EKPC}$, że gwarancja prawna do rozpatrzenia sprawy w rozsądnym terminie nie stanowi wartości samej w sobie, lecz służy realizacji prawa do sprawiedliwego i publicznego rozpatrzenia sprawy przez niezawisły i bezstronny sąd ustanowiony ustawą.

W uchwale z 28 czerwca 2005 r. (III SPZP 1/05) Sąd Najwyższy poczynił rozróżnienie, że w sensie funkcjonalnym kwestia zarzutu przewlekłości postępowania ma charakter pochodny i incydentalny względem postępowania pierwotnego, ale $\mathrm{w}$ sensie prawnoprocesowym postępowanie ze skargi na przewlekłość jest odrębne względem postępowania, którego dotyczy. Jako argumenty za odrębnościa postępowania w przedmiocie przewlekłości Sąd Najwyższy przytoczył: odmienny przedmiot i cel tego postępowania, inne strony, inny sąd właściwy do rozpoznania skargi, stosowanie w zakresie nieuregulowanym odpowiednio przepisów o postępowaniu zażaleniowym obowiązującym w postępowaniu, którego skarga dotyczy, skutek prejudycjalny orzeczenia dla sądu cywilnego, wyłączną właściwość sądów do rozpoznania skargi ${ }^{14}$. Ostatecznie Sąd Najwyższy odszedł od koncepcji postępowania

${ }^{11}$ Za stanowiskiem Sądu Najwyższego wyrażonym w uchwale z 23 marca 2006 r., III SPZP 3/2005, OSNP 2006, nr 21-22, poz. 341, która uzyskała moc zasady prawnej, opowiedział się Trybunał Konstytucyjny w wyroku z 1 kwietnia 2008 r., SK 77/06, OTK-A 2008, nr 3, poz. 39, Dz. U. 2008, Nr 59, poz. 367. (Por. postanowienie z 9 listopada 2005 r., TS 89/05, OTK-B 2006, nr 5, poz. 180, Trybunał Konstytucyjny stwierdził, że postępowanie o stwierdzenie przewlekłości postępowania sądowego ma charakter incydentalny, dlatego ustawodawca ukształtował je jako jednoinstancyjne).

${ }^{12} \mathrm{~W}$ glosie do uchwały z 23 marca 2006 r. III SPZP 3/05, wskazano na niemające uzasadnienia w racjonalnych i konstytucyjnie umocowanych kryteriach zróżnicowanie sytuacji strony wnoszącej skargę na przewlekłość od sytuacji strony, która praw dochodzi w klasycznym modelu procesu na podstawie art. 417 k.c. Strona, która wniosła skargę, wykazuje przewlekłość w jednoinstancyjnym, niejawnym postępowaniu bez możliwości kwestionowania ustaleń postępowania dowodowego oraz odwołania, natomiast w ,klasycznym” modelu postępowania cywilnego strona korzysta ze wszystkich środków proceduralnych oraz apelacji (B. Błońska, G. Rząsa, Glosa do uchwaty siedmiu sędziów z dnia 23 marca 2006 r. III SPZP 3/05, „Przegląd Sądowy” 2008, nr 9, s. 132-133).

${ }^{13}$ Uchwała Sądu Najwyższego z 28 czerwca 2005 r., III SPZP 1/05, OSNP 2005, nr 19, poz. 312.

14 Por. G. Artymiak, Zasada szybkości postępowania karnego. Uwag kilka na tle ustawy o skardze na naruszenie prawa strony do rozpoznania sprawy w postępowaniu sqdowym bez nieuzasadnionej zwtoki, „Wojskowy Przegląd Prawniczy” 2005, nr 1, s. 28; D. Szumiło-Kulczycka, Ustawa o skardze na naruszenie prawa strony do rozpoznania sprawy $w$ postepowaniu sqdowym bez zbędnej zwtoki w świetle orzecznictwa $i$ danych empirycznych, w: S. Waltoś, J. Czapska (red.), Zagubiona szybkość procesu karnego. Swiatto w tunelu, Kraków 2007, s. 47-57. 
pierwotnego i w uchwale z 23 marca 2006 r. (III SPZP 3/05) opowiedział się za incydentalnym charakterem postępowania w przedmiocie przewlekłości.

Następnie Trybunał Konstytucyjny w wyroku z 1 kwietnia 2008 r. (SK 77/06) poparł stanowisko Sądu Najwyższego wyrażone w uchwale z 23 marca 2006 r. (III SPZP 3/2005). Trybunał podzielił ocenę, że skarga na przewlekłość ma charakter gwarancji prawa do sądu. Wedle tego stanowiska gwarancja wolności i praw konstytucyjnych jest dwustopniowa, podstawowa gwarancję tych wolności i praw stanowi prawo do sadu, a gdyby prawo to nie było właściwie realizowane, stronie przysługuje subsydiarna skarga na przewlekłość postępowania ${ }^{15}$. W wyroku tym Trybunał Konstytucyjny zmierzył się z problemem, czy Konstytucja nakazuje stworzenie mechanizmu badania zgodności z prawem prawomocnych orzeczeń sądowych niekończących postępowania w sprawie, i rozstrzygnął, że wszelkie mechanizmy kontroli prawomocnych rozstrzygnięć niekończących postępowania w sprawie, wydanych w toku postępowania, moga prowadzić do podważania autorytetu władzy sądowniczej i stabilności orzeczeń kończących postępowanie w sprawie.

Trybunał wskazał, że jeżeli rozstrzygnięcie sądu w kwestii wpadkowej warunkuje poprawność rozstrzygnięcia merytorycznego i podlega rozpoznaniu przy okazji kontroli orzeczenia merytorycznego przez sąd wyższej instancji, a ewentualna szkoda jest konsekwencją orzeczenia merytorycznego, to nie zachodzi potrzeba tworzenia odrębnych procedur kontroli rozstrzygnięć wpadkowych ${ }^{16}$. W ocenie Trybunału konstytucyjne zasady sprawiedliwej procedury sądowej oraz dwuinstancyjności postępowania nie wymagaja, aby od każdego rozstrzygnięcia o charakterze incydentalnym przysługiwały zawsze środki zaskarżenia, ale ustawodawca musi umożliwić zainteresowanym skuteczne dochodzenie wynagrodzenia szkody, jeżeli rozstrzygnięcia takie zostały wydane $\mathrm{z}$ naruszeniem prawa $\mathrm{i}$ spowodowały szkody majątkowe lub niemajątkowe, a jednocześnie nie jest możliwe dochodzenie tych szkód w postępowaniu mającym za przedmiot szkody wyrządzone prawomocnym orzeczeniem kończącym postępowanie.

Przełożenie powyższej tezy wyrażonej w wyroku Trybunału Konstytucyjnego na obszar postępowania karnego prowadzi do wniosku, że orzeczenie stwierdzające przewlekłość postępowania nie może podlegać kontroli instancyjnej, na przykład w drodze apelacji. Jeżeli na przykład nie przysługuje zażalenie na wpadkowe postanowienie o oddaleniu wniosku dowodowego w postępowaniu karnym, to można się do tej kwestii odnieść w zarzutach apelacyjnych, co zostanie rozważone przez sąd odwoławczy. W sytuacji braku możliwości zaskarżenia orzeczenia wydanego $\mathrm{w}$ przedmiocie przewlekłości

${ }^{15}$ Por. M. Haczkowska, Odpowiedzialność odszkodowawcza państwa wedtug Konstytucji RP, Warszawa 2007.

${ }^{16}$ Europejski Trybunał Praw Człowieka w wyroku z 26 października 2000 r., nr 30210/96, sprawa Kudta przeciwko Polsce (Lex nr 42804), wskazał, że środek odwoławczy wymagany przez art. 13 Konwencji musi być ,skuteczny” pod względem praktycznym i prawnym, jeśli pojedynczy środek odwoławczy nie spełnia wymogów art. 13, wymaganiom tego artykułu może sprostać całość środków odwoławczych przewidzianych przez prawo wewnętrzne (por. C. P. Kłak, Skarga na przewlektość postepowania karnego a Europejska Konwencja o Ochronie Praw Człowieka i Podstawowych Wolności, Rzeszów 2011; idem, Pojęcie przewlektości postępowania sadowego, „Prokuratura i Prawo” 2008, nr 12, s. 79). 
zarzuty, które byłyby podstawą takiego zażalenia, nie będą podlegały rozważeniu przez sąd meriti ani odwoławczy, co przemawia pośrednio za uznaniem postępowania w przedmiocie przewlekłości postępowania głównego za postępowanie odrębne. W postępowaniu inicjowanym skarga badana jest szybkość prowadzenia postępowania głównego, ponadto toczy się ono pomiędzy innymi stronami niż postępowanie główne, a stosunki procesowe ${ }^{17}$ łączą inne podmioty niż w głównym postępowaniu karnym: 1) sąd (przełożony nad sądem, przed którym toczy się postępowanie, lub nad tym, który byłby właściwy rzeczowo do rozpoznania sprawy), 2) Skarb Państwa (oparty na konstrukcji cywilnoprawnej), który może działać na prawach strony, oraz 3) skarżący (strona oraz pokrzywdzony, nawet jeżeli nie jest stroną). W postępowaniu tym występuje nowy podmiot niewystępujący w postępowaniu zasadniczym, gdyż Skarb Państwa reprezentuje tu inny organ niż prowadzący postępowanie główne. Pojawia się pytanie, czy procedura, w której występują inne strony, może być jeszcze traktowana jako incydentalna. Kwestia, czy jest to pozakodeksowe postępowanie wpadkowe, czy też odrębne, $\mathrm{z}$ teoretycznego punktu widzenia jest otwarta, o czym świadczą wspomniane dwie przeciwstawne uchwały Sądu Najwyższego.

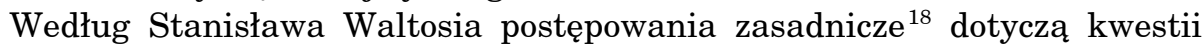
rozstrzygania odpowiedzialności karnej, a dodatkowe prowadzone są w związku z postępowaniem zasadniczym. Do postępowań dodatkowych S. Waltoś zalicza postępowania: incydentalne, pomocnicze, następcze, uzupełniające. W postępowaniu incydentalnym rozważane sa takie kwestie dodatkowe powstające podczas toczącego się postępowania zasadniczego, jak tymczasowe aresztowanie lub zabezpieczenie majątkowe. Postępowanie pomocnicze służy usuwaniu szczególnych trudności w toku procesu ( $\mathrm{np}$. międzynarodowa pomoc prawna); postępowanie następcze dotyczy okresu po uprawomocnieniu się wyroku (np. procedura ułaskawienia); postępowanie uzupełniające prowadzone jest na podstawie art. 420 k.p.k. i dotyczy uzupełnienia wyroku ${ }^{19}$. Biorąc pod uwage powyższe rozróżnienia, nasuwa się wniosek, że postępowanie w przedmiocie przewlekłości wymyka się od przyporządkowania do któregokolwiek z typów postępowania. Wydaje się, że spowodowane jest to przyjęciem hybrydowego modelu postępowania inicjowanego skargą, łączącego elementy kompensacyjne z nadzorczymi. Jednakże nawet w przypadku uznania, że jest to postępowanie sui generis, procedura powinna zostać prawidłowo ukształtowana.

W doktrynie wskazano, że art. 8 ust. 2 ustawy o skardze odsyła do odpowiedniego stosowania przepisów ogólnych postępowania odwoławczego oraz przepisów o zażaleniu zawartych w rozdziałach 48 i 50 k.p.k., rozwiązanie to jest krytykowane ze względu na zbytnią ogólność, stąd podnosi się, aby kwestie objęte odesłaniem dotyczące zaskarżania orzeczeń uregulować szczegółowo w samej ustawie ${ }^{20}$. Konsekwencją odpowiedniego zastosowania

${ }_{17}$ Por. T. Grzegorczyk, J. Tylman, Polskie postepowanie karne, Warszawa 2007, s. 47-51.

${ }_{18}$ Por. A. Swiatłowski, Jedna czy wiele procedur karnych. Z zagadnień wewnętrznego zróżnicowania form postepowania karnego rozpoznawczego, Sopot 2008.

19 S. Waltoś, Proces karny. Zarys systemu, Warszawa 2005, s. 43-44.

${ }^{20}$ W. Jasiński, w: Skarga na naruszenie prawa strony do rozpoznania sprawy bez nieuzasadnionej zwtoki. Komentarz, J. Skorupka (red.), Warszawa 2010, s. 186-187, 204-205; M. Kłopocka, Skarga na 
przepisów k.p.k. o zażaleniu jest to, że sąd rozpoznaje skargę na posiedzeniu. Zdaniem Piotra Góreckiego, Stanisława Stachowiaka, Pawła Wilińskiego i Moniki Zbrojewskiej, na podstawie art. $464 \S 2$ k.p.k. sąd może zezwolić stronom na wzięcie udziału $\mathrm{w}$ posiedzeniu, przy czym - zgodnie $\mathrm{z}$ zasadą kontradyktoryjności - sąd powinien udzielać takiego zezwolenia, gdyż takie rozpoznanie sprawy ułatwia ustalenie przyczyn długotrwałości postępowania i ocenę wchodzącej w grę przewlekłości ${ }^{21}$. W doktrynie wskazano, że jeżeli na podstawie art. 10 ust. 3 wyżej wspomnianej ustawy udział w postępowaniu dotyczącym skargi zgłosi przedstawiciel Skarbu Państwa, to przysługuje mu na podstawie art. 8 ust. 2 ustawy o skardze na przewlekłość w związku z art. 428 $\S 2$ k.p.k. uprawnienie do wniesienia odpowiedzi na skargę ${ }^{22}$.

Wybór przepisów Kodeksu postępowania karnego stosowanych odpowiednio w zakresie zaskarżania orzeczeń sądu w przedmiocie przewlekłości zależy zatem od rozważenia kwestii wstępnej, czy sąd ten działa jako pierwsza, czy druga instancja. Jeżeli działa jako pierwsza instancja, to rozpatruje nowa sprawę, jeżeli działa jako instancja odwoławcza, rozpoznaje sprawę pochodną powstała podczas rozpoznawania sprawy głównej, a następstwem tego jest przyjęcie, że postępowanie ze skargi na przewlekłość postępowania karnego jest postępowaniem incydentalnym. Dokonanie takiego wyboru przez doktrynę i orzecznictwo powinno nastąpić z uwzględnieniem całego systemu prawa, w tym Konstytucji.

\section{NIEJASNA POZYCJA SKARBU PAŃSTWA W HYBRYDOWYM MODELU POSTEPOWANIA}

Skutki orzeczenia stwierdzającego przewlekłość dotykają dwóch podmiotów publicznoprawnych - Skarbu Państwa, który ponosi odpowiedzialność majątkowa, oraz organu procesowego prowadzącego postępowanie karne, który może zostać zobowiązany przez sąd do wykonania odpowiednich czynności i dotykaja go konsekwencje służbowe związane $\mathrm{z}$ uwzględnieniem skargi. Na tym tle nasuwaja się pytania, czy podmioty reprezentujące Skarb Państwa zostały w ustawie właściwie wskazane oraz czy ustawa powinna przewidywać możliwość przedstawienia własnego stanowiska co do zarzutów skargi również organowi prowadzącemu postępowanie, któremu zarzucono przewlekłość, a nie jak dotychczas - tylko organowi reprezentującemu Skarb Państwa. Wydaje się, że organ procesowy prowadzący postępowanie karne, pod którego adresem kierowane sa zarzuty skargi, powinien mieć prawo do informacji o treści zarzutów oraz prawo do co najmniej pisemnego wyrażenia własnego stanowiska co do zarzutów przed sądem rozpoznającym skargę. Wynika to $\mathrm{z}$ zasady

\footnotetext{
przewlektość $w$ postepowaniu sqdowym (ze szczególnym uwzględnieniem przepisów postẹpowania karnego), w: L. Bogunia (red.), Nowa kodyfikacja prawa karnego, t. 19, Wrocław 2006, s. 155 i 167.

${ }^{21}$ P. Górecki, S. Stachowiak, P. Wiliński, Skarga na przewlektość postepowania przygotowawczego i sadowego. Komentarz, Warszawa 2010, s. 91-92; M. Zbrojewska, Skarga na przewlektość postępowania karnego, „Palestra” 2004, nr 11-12, s. 28.

${ }^{22}$ W. Jasiński, op. cit., s. 187; M. Zbrojewska, op. cit., s. 28.
} 
kontradyktoryjności i wysłuchania drugiej strony oraz jest uzasadnione tym bardziej, że właśnie tego organu dotycza konsekwencje służbowe i to on wykonuje czynności wskazane przez sąd. W ustawie całkowicie pominięto możliwość przedstawienia własnego stanowiska przez organ, który postępowanie stojące pod zarzutem przewlekłości prowadzi.

W przyjętym modelu postępowania inicjowanego skarga również usytuowanie Skarbu Państwa jest problematyczne. Marta Romańska zwróciła uwagę, że sąd jako podmiot prawa publicznego może naruszyć publiczne prawo podmiotowe skarżącego, przy czym sąd jest powiązany ze Skarbem Państwa tylko w sferze prywatnoprawnej. Ustawodawca w postępowaniu zainicjowanym skarga odwołał się do cywilnej konstrukcji Skarbu Państwa, jako podmiotu posiadającego osobowość prawną, zdolność prawną i prawa majątkowe, czyli zdolnego do wypłaty odpowiedniej sumy pieniężnej. Skutkiem zastosowania art. 10 ustawy o skardze na przewlekłość jest to, że $\mathrm{w}$ incydentalnym postępowaniu prowadzonym w toku sprawy głównej może pojawić się podmiot niebiorący dotychczas udziału w sprawie i który nie jest jego stroną ${ }^{23}$.

Kwestia ochrony interesów Skarbu Państwa w toku postępowania zainicjowanego skarga została rozważona w uzasadnieniu uchwały Sądu Najwyższego z 23 marca 2006 r. (III SPZP 3/05) w sposób niedostateczny. Sąd Najwyższy oceny tej kwestii dokonał tylko poprzez wskazanie różnicy, że z perspektywy konstytucyjnej ochrona prawa do sądu nie odnosi się do podmiotów prawa publicznego, lecz jednostki ze względu na usytuowanie art. 45 Konstytucji RP w rozdziale drugim: „Wolności, prawa i obowiązki człowieka i obywatela”. Sąd doszedł do wniosku, że Skarb Państwa i komornik nie moga wywodzić prawa do odwołania od postanowienia zapadłego w przedmiocie przewlekłości z zasady dwuinstancyjności postępowania sądowego będącej emanacją zasady prawa do sądu (art. 176 ust. $1 \mathrm{w}$ związku z art. 45 Konstytucji). W uchwale tej Sąd Najwyższy wskazał ponadto, że samo Państwo tak ukształtowało procedurę w zakresie rozpoznania skargi, że nie przewiduje ona możliwości odwołania od postanowienia sądu w przedmiocie przewlekłości, ponadto Skarb Państwa w postępowaniu w przedmiocie przewlekłości nie występuje jako równorzędny podmiot stosunku cywilnoprawnego o charakterze majątkowym, gdyż jego odpowiedzialność dotyczy tu działań ze sfery imperium, nie zaś dominium ${ }^{24}$.

Obecna regulacja przewiduje udział w postępowaniu i możliwość ustosunkowania się do skargi tylko organom reprezentującym Skarb Państwa, nie daje zaś takich możliwości organom procesowym, które zaskarżone postępowanie prowadza. Należałoby rozważyć wprowadzenie wymogu zwracania się przez sąd rozpoznający skargę o pisemne stanowisko co do zarzutu przewlekłości do dwóch podmiotów: 1) sądu lub prokuratora, który prowadzi postępowanie, oraz 2) prezesa sądu lub prokuratora przełożonego jako przedstawiciela Skarbu Państwa ponoszącego konsekwencje majątkowe. W praktyce sąd dysponuje

\footnotetext{
${ }^{23}$ M. Romańska, Skarga na przewlektość postępowania sadowego, „Przegląd Sądowy”2005, nr 11-12, s. 50-51.

${ }^{24} \mathrm{Na}$ temat odpowiedzialności komornika realizującego funkcje władzy publicznej, por. wyrok Trybunału Konstytucyjnego z 20 stycznia 2004 r., SK 26/03, OTK-A 2004, nr 1, poz. 3.
} 
tylko stanowiskiem reprezentanta Skarbu Państwa. W zakresie postępowania przygotowawczego oświadczenie co do przewlekłości organu faktycznie prowadzącego postępowanie pozostaje tylko w aktach podręcznych sprawy, które do sądu nie są przesyłane. W niektórych przypadkach stanowisko prokuratora prowadzącego postępowanie i stanowisko prokuratora przełożonego (tu reprezentanta Skarbu Państwa) może się nawet różnić, co wynika z wielu czynników związanych z zasadami, na jakich działa prokuratura, oraz rozkładu odpowiedzialności za uchybienia.

Problem przesyłania do sądu rozpoznającego skargę tylko akt głównych postępowania przygotowawczego pojawia się też w kontekście dokonywania przez sąd merytorycznej oceny zarzutów skargi. Taktyka czynności procesowych oraz współpraca $\mathrm{z}$ organami ścigania odzwierciedlona jest w aktach podręcznych sprawy, akta główne odbijają tylko wyniki przeprowadzonych czynności, często brak w nich wytłumaczenia długiego czasu wykonywania wytycznych i swoistej kuchni postępowania ${ }^{25}$. Praktyka przesyłania tylko akt głównych połączona $\mathrm{z}$ brakiem możliwości zaskarżenia orzeczenia przez organ reprezentujący Skarb Państwa oraz brakiem przepisów proceduralnych umożliwiających przedstawienie sądowi rozpoznającemu skargę stanowiska organu prowadzącego postępowanie wydaje się niesłuszna i prowadzi do kolejnego problemu, mianowicie: bezstronności sądu lub prokuratora prowadzącego sprawę po wydaniu orzeczenia uwzględniającego skargę.

Jeżeli chodzi o uprawnienia procesowe przewidziane w ustawie dla organu reprezentującego Skarb Państwa, to nie sa one zagwarantowane wtedy, gdy dojdzie do pomyłki proceduralnej sądu polegającej na zaniechaniu powiadomienia o postępowaniu i doręczenia odpisu skargi reprezentantowi Skarbu Państwa, który zostaje wtedy pozbawiony możliwości wyrażenia własnej oceny na temat zarzutu przewlekłości oraz możliwości działania na prawach strony w postępowaniu zainicjowanym skargą. Można sobie wyobrazić scenariusz, w którym sąd rozpoznający skargę na przewlekłość popełnia błąd o charakterze proceduralnym i zapomina o zastosowaniu art. 10 ustawy $^{26}$. Brak ten, po wydaniu przez sąd orzeczenia, nie podlega konwalidacji, gdyż ustawa nie przewiduje możliwości zaskarżania postanowienia $\mathrm{z}$ powodu błędów proceduralnych. Wynika stąd, że tylko $\mathrm{w}$ prawidłowo przebiegającej procedurze

${ }^{25}$ I. Nowikowski zwrócił uwagę na przewlekłość postępowania spowodowaną przesyłaniem do sądu oryginałów akt w celu rozpoznania skargi oraz poddał pod rozwagę praktykę przesyłania kopii akt, nawiązując do koncepcji A. Murzynowskiego rozpatrywania wniosków i zażaleń w przedmiocie tymczasowego aresztowania (I. Nowikowski, W kwestii skargi na nierozpoznanie sprawy $w$ rozsadnym terminie $w$ postępowaniu karnym (zagadnienia wybrane), w: A. Marek (red.), Wspótczesne problemy procesu karnego i jego efektywności. Księga pamiatkowa Profesora Andrzeja Bulsiewicza, Toruń 2004, s. 283-298).

${ }^{26}$ Sytuacja taka zdarzyła się na gruncie postępowania cywilnego i została rozpatrzona przez Sąd Najwyższy w uchwale z 28 czerwca 2005 r., sygn. III SPZP 1/0 5, „,Biuletyn Sądu Najwyższego” 2005, nr 6, s. 20. Uczestnik postępowania Prezes Sądu Okręgowego we Wrocławiu wniósł o wznowienie postępowania na podstawie art. 399 k.p.c., podnosząc naruszenie art. 10 ust. 1 i 3 ustawy o skardze na przewlekłość poprzez niedoręczenie Skarbowi Państwa odpisu skargi i pozbawienie możności działania. Sąd Najwyższy orzekł, że niedopuszczalna jest tu skarga o wznowienie postępowania, jednak wniesiona przez Sąd Okręgowy skarga o wznowienie powinna zostać potraktowana przez Sąd Apelacyjny jako zażalenie na postanowienie tego Sądu. Teza o potraktowaniu skargi o wznowienie jako zażalenia z oczywistych powodów nie może zostać przełożona na grunt procesu karnego. 
Skarb Państwa skorzysta ze swoich uprawnień. Przenosząc ten casus na grunt procedury karnej, pomimo obrazy przepisów postępowania mogącej mieć wpływ na treść orzeczenia (art. 438 pkt 2 k.p.k.), orzeczenie zapadłe w wadliwej procedurze nie będzie mogło zostać wyeliminowane $\mathrm{z}$ obrotu prawnego.

Oskarżony (podejrzany) oraz pokrzywdzony, mimo braku możliwości zaskarżenia orzeczenia stwierdzającego przewlekłość, w odróżnieniu od Skarbu Państwa, dysponuja innymi środkami ochrony swoich praw. Strona, której skargę uwzględniono, może w odrębnym postępowaniu dochodzić naprawienia szkody wynikłej ze stwierdzonej przewlekłości od Skarbu Państwa albo solidarnie od Skarbu Państwa i komornika, a postanowienie uwzględniające skargę wiąże sąd $\mathrm{w}$ postępowaniu cywilnym ${ }^{27}$. Ponadto strona, która nie wniosła skargi na przewlekłość postępowania, może dochodzić naprawienia szkody wynikłej z przewlekłości na podstawie art. 417 k.c. po prawomocnym zakończeniu postępowania co do istoty sprawy. Skarb Państwa dopiero jako pozwany $\mathrm{w}$ postępowaniu cywilnym uzyskuje właściwe prawa strony, do których zalicza się prawo zaskarżenia postanowienia sądu, przytaczanie argumentów dotyczących miarkowania odszkodowania czy przyczynienia się do przewlekłości przez stronę dochodzącą odszkodowania.

Model postępowania w przedmiocie przewlekłości postępowania głównego ma charakter hybrydowy, gdyż oprócz cech postępowania kompensacyjnego, nosi cechy postępowania nadzorczego (istnienie dwóch mechanizmów w ustawie stwierdził Sąd Najwyższy w uchwale z 23 marca 2006 r., III SPZP 3/2005). Sąd orzekający w przedmiocie przewlekłości może bowiem zlecić wykonanie przez sąd lub prokuratora rozpoznającego sprawę co do istoty odpowiednich czynności w wyznaczonym terminie, przy zastrzeżeniu, że zalecenia te nie będą wkraczać w zakres oceny faktycznej i prawnej sprawy. W każdym przypadku, gdy zostanie wydane orzeczenie uwzględniające skargę na przewlekłość postępowania, jego odpis doręczany jest przez sąd odpowiednio prezesowi właściwego sądu albo prokuratorowi przełożonemu, a organy te są obowiązane do podjęcia czynności nadzoru przewidzianych w ustawie z 27 lipca 2001 r. - Prawo o ustroju sądów powszechnych albo ustawie z 20 czerwca 1985 r. o prokuraturze. Wątpliwości wzbudza obligatoryjność wszczynania co najmniej postępowania wyjaśniającego, które może przerodzić się w postępowanie dyscyplinarne, w szczególności gdy przyczynami przewlekłości były stwierdzone braki kadrowe i niedowład organizacyjny, wtedy zasądzana suma pieniężna obciąża budżet niedomagającego sądu lub prokuratury.

$\mathrm{Na}$ tle obligatoryjności podejmowania czynności nadzoru rysuje się po raz kolejny problem bezstronności organu procesowego po stwierdzeniu przez sąd przewlekłości. W postępowaniu karnym spotykana jest praktyka wydawania postanowień o zabezpieczeniu majątkowym na mieniu oskarżonego odpowiadającym sumie pieniężnej przyznanej mu przez sąd na skutek stwierdzenia przewlekłości. Szczególnie w postępowaniu sądowym, ze względu na konsekwencje wyłączenia sędziego, skarga na przewlekłość może być składana w celu

${ }^{27} \mathrm{Na}$ temat przesłanek stwierdzenia przewlekłości postępowania sądowego, por. K. Gonera, Przewlektość postępowania w sprawach cywilnych, „Przegląd Sądowy” 2005, nr 11-12, s. 14-15 i 18-36. 
wywołania dalszej przewlekłości w sprawach, w których upływają terminy przedawnienia.

W kontekście przepisów postępowania karnego stosowanych odpowiednio, należy zważyć, że sama zasada szybkości postępowania jest zasadą pomocniczą, która zawsze musi ustapić, jeżeli wchodzi w konflikt z zasadami naczelnymi procesu karnego ${ }^{28}$. W postępowaniu zainicjowanym skargą zasadniczą kwestia jest prawidłowe rozstrzygnięcie o tym, czy przewlekłość wystapiła, a jeżeli tak, to podjęcie dwutorowej reakcji majątkowej i dyscyplinującej. Argument szybkości postępowania poprzez rezygnację z wprowadzenia środków zaskarżenia orzeczeń nie jest przekonujący.

\section{W KIERUNKU WIEKSZEJ KONTRADYKTORYJNOŚCI POSTEPOWANIA}

Stwierdzenie przewlekłości postępowania rodzi konsekwencje o charakterze majątkowym dla Skarbu Państwa oraz służbowym dla organu prowadzącego postępowanie karne. Ze względu na obligatoryjność zasądzania sumy pieniężnej oraz wdrażania czynności nadzoru, czyli w istocie formy postępowania wyjaśniającego, które może przekształcić się w postępowanie dyscyplinarne, konsekwencje majątkowe i służbowe będą towarzyszyły orzeczeniu stwierdzającemu przewlekłość postępowania zawsze. Utrzymanie hybrydowego modelu postępowania wymaga wprowadzenia zmian w ustawie dla zapewnienia sprawiedliwej procedury. Do ustawy o skardze na przewlekłość postępowania powinny zostać wprowadzone elementy gwarantujące równouprawnienie dwóch w istocie stron tego postępowania - skarżącego i reprezentanta Skarb Państwa. Ponadto sąd powinien zapoznać się co najmniej z pisemnym stanowiskiem organu procesowego, któremu faktycznie zarzucono przewlekłość procedowania. Kontradyktoryjność postępowania jest szczególnie uzasadniona w zakresie odpowiedzialności majątkowej Skarbu Państwa, gdyż ustawa odwołuje się tu do cywilnej konstrukcji Skarbu Państwa. Sąd rozpoznający skargę powinien kierować się zasadą Audi alteram partem. Uzasadnienie utrzymania obecnego modelu postępowania w przedmiocie przewlekłości postępowania karnego, które oparte jest na zasadzie pomocniczej szybkości postępowania, jest wysoce niewystarczające i wpływa negatywnie na bezstronność organu prowadzącego postępowanie. W ustawie o skardze na przewlekłość postępowania nie przewidziano możliwości przedstawienia własnego stanowiska co do zarzutów skargi przez organ, który faktycznie prowadzi postępowanie karne, a uprawnienia takie przewidziano tylko dla reprezentanta Skarb Państwa. W tym ostatnim przypadku w ustawie zabrakło

\footnotetext{
${ }^{28}$ Według Z. Świdy, zasada rzetelnego procesu wymaga pogodzenia nakazu sprawnego postępowania z prawidłowym wymiarem sprawiedliwości, prawo do rzetelnego procesu może zostać naruszone, nawet jeżeli nie naruszono żadnego ze szczególnych praw z art. 6 EKPC, natomiast naruszono zasady dotyczące prawidłowego przebiegu postępowania (idem, Wtaściwość sadu i prawo strony do rozstrzygania sprawy „w rozsadnym terminie”, „Państwo i Prawo” 2005, z. 10, s. 47 i 48).
} 
gwarancji realizacji uprawnień Skarbu Państwa, gdyż nie ma możliwości zaskarżenia orzeczenia na podstawie naruszenia przepisów proceduralnych. Rozwiązania takie w świetle przytaczanych argumentów odnoszących się w głównej mierze do szybkości postępowania, kwestii ważnej, ale pobocznej, nie dają się obronić w świetle naczelnych zasad polskiego procesu karnego.

mgr Ariadna Ochnio

Instytut Nauk Prawnych Polskiej Akademii Nauk w Warszawie

SOME REMARKS ON THE PROCEDURAL FAIRNESS

OF A COMPLAINT AGAINST EXCESSIVE LENGTH OF CRIMINAL PROCEEDINGS

\section{Summary}

The paper discusses a model of proceedings initiated by a complaint against excessive length of criminal proceedings introduced in the Act of 17 June 2004 on a complaint against violation of a party's right to have a case examined without undue delay preparatory and judicial proceedings (Journal of Laws 2004, No. 179, item. 1843 as amended). A legislative solution which does not provide for the possibility of appeal against a judgment on lengthiness raises the question of the constitutionality and procedural fairness of such regulation. Moreover, it is unclear whether such a solution was intentional, or is the result of so-called legislative 'omission'. The existence of the right to appeal against the judgment is a consequence of the choice between the model of incidental proceedings and proceedings on the merits, which reflects the jurisprudence of the Constitutional Court (Trybunat Konstytucyjny) and the Supreme Court. The civil law structure of the State Treasury for the purposes of liability for damages used in the Act, together with a simultaneous limitation of the application of elements of adversarial proceedings, makes the position of the Treasury in the course of the proceedings rather problematic. The existing law requires amendments towards an increased involvement of the contradictory elements. Recognition of the current model of proceedings based on the auxiliary principle of the rapidity as satisfactory would be highly inappropriate in light of the guiding principles of the Polish criminal procedure. 
